\title{
Provincial Governance Quality and Earnings Management: Empirical Evidence from Vietnam
}

\author{
Anh Huu NGUYEN*, Chi Thi DUONG** \\ Received: November 16, 2019 Revised: December 11, 2019 Accepted: December 18, 2019
}

\begin{abstract}
The paper investigates the mechanism through which corporate credit ratings affect dividend payments by decomposing the mean difference of dividends into a part that is explained by the determinants of dividends and a residual part that is contributed by the pure credit group effect, in the framework of the traditional dividend model of Fama and French (2001). Historically, better credit rated firms have shown consistently higher propensity to pay dividends especially during the economic crisis period. According to the counter-factual decomposition technique of Jann (2008), better rated firms are more responsive to the firm characteristics that have positive impact on dividends and poor rated firms are more responsive to the negative dividend predictors. As a result, good (bad) credit ratings make corporate managers become more bold (timid) in their dividend payments and they tend to pay more (less) dividends than what their firm characteristics prescribe. The degree of information asymmetry increases for the poor group firms during crisis periods and they attempt to reserve more cash in preparation for future investments. The decomposition results suggest that the credit group effect can potentially exceed the effect of firm characteristics because firms of different credit ratings can respond to the very same firm characteristics in a different manner.
\end{abstract}

Keywords : Credit Rating, Dividend, Financial Crisis, Firm Characteristic, Information Asymmetry

JEL Classification Code : G01, G10, G30, G35

\section{Introduction}

Earnings management has been much researched over several decades by scholars over the world. One of the common accepted definition of earnings management concept is Healy and Wahlen (1999) argue that earnings management occurs when managers use judgment in financial reporting and in structuring transactions to alter financial reports to either mislead some stakeholders about the underlying economic performance of the company or to influence "contractual outcomes that depend on reported

${ }^{*}$ First Author and Corresponding Author. Associate Professor in Accounting, Dean, School of Accounting and Auditing, National Economics University, Vietnam [Postal Address: 207 Giai Phong Road, Hai Ba Trung District, Hanoi City, 100000, Vietnam], Tel. (+84) 906163535, Email: anhnh@neu.edu.vn

**Lecturer, School of Accounting and Auditing, PhD Candidate, National Economics University, Vietnam.

Email: duongchi@neu.edu.vn

○) Copyright: Korean Distribution Science Association (KODISA)

This is an Open Access article distributed under the terms of the Creative Commons Attribution NonCommercial License (https://creativecommons.org/licenses/by-nc/4.0/) which permits unrestricted noncommercial use, distribution, and reproduction in any medium, provided the original work is properly cited. accounting numbers" (1999, p.368). Thus, earnings management has been studied extensively in finance and related fields. Prior empirical studies have mainly focused on traditional factors, which is business characteristics are measured by audit quality, company size, debt, and performance affecting earnings management in both developed and developing countries. Up to date, just few researches have been conducted to explore the impact of external factors on earnings management.

According to Hoskisson, Eden, Lau, and Wright (2000) the institutional theory emphasizes the impacts of the systems surrounding firms to explain firm behavior in the transitional economies. This approach indicates that institutions may affect earnings management. Recently, a growing body of international research in the body of literature has emerged to examine the relationship between institutional factors and earnings management such as Kimbro (2002), Wu (2005), Malagueno, Albrecht, Ainge, and Stephens (2010), Memis and Cetenak (2012), González and Meca (2014), Houqe and Monem (2016). Additionally, political and economic differences in the institutional 
backgrounds between mature and emerging markets are large differences, which is clearly observable. The relationship has been examined over many years in various countries and has been widely verified. Thus, authors find the best proxy to measure institutional factor in different environment to test how institutional factor incentives for firms to manipulate earnings.

Measuring institutional factors by legal system, investor protection were found on several studies (Houqe \& Monem, 2016; Kimbro, 2002; LaPorta, Lopez-de-Silanes, Shleifer, \& Vishny, 1998; Leuz, Nanda, \& Wysocki, 2003; Malagueno, Albrecht, Ainge, \& Stephens, 2010; Memis \& Cetenak, 2012; Wu, 2005) use corruption index as another variable. In addition, political connections, political costs were used in several researches (Chen, Liang, \& Wang, 2011; Ngo \& Susnjara, 2017). Effectiveness of the government was found in research of González and Meca (2014). Most of studies conclude that firm's institutional environment determines earnings level of manipulations. However, there are a limited number of existing researches in transition and emerging countries as well as, these were a little consensus in previous literature on whether it is applicable to Vietnam. Thus, this study aims to address following questions. Which suitable variables to measure institutional characteristics for factors listed companies in Vietnam? Do institutional factors effect on earnings management of Vietnamese firms?

In this study, we will investigate earnings management and institutional factors measured by provincial governance quality, which is different from the measurement of institutions found in previous studies. Several contributions to the literature on earnings management can be found in this paper. First, almost studies use perception corruption index as proxy to measure institution instead of real phenomenon, this measurement is known as indicator cannot capture the level of corruption very well. In this research we use the both measures corruption and institutional quality at provincial level to deal with this limitation. Further, existing the asymmetric effects of the country policies and governance quality found in different provinces is differed. These findings enrich understanding of the impact of governance quality in the institutional setting of Vietnam. Objectives are achievable goals so the purpose of the present study is to examine the effect of provincial governance quality on earnings management in construction and materials sector in Vietnam.

The remainder of the paper is structured as follows: In Section 2, Literature Review. Section3 demonstrate Research Hypotheses; Section 4, presents the Research Methodology; Results and Discussion about the impact of provincial governance quality on earnings management in Section 5. Finally, Implications and Conclusion are explained in Section 6.

\section{Literature Review}

Many studies on earnings management consider institutions as a factor influencing earnings management. However, various institutions such as political and economic, system and form of governance are quite different between countries. Ball, Kothari, and Robin (2000) suggested that earnings quality in accounting is systematically different in common-law countries versus code-law countries. Thus country-level institutional differences affect on earnings management. It raises a series of alternative measures institutions to find a suitable proxy for each reseach. As the result, in majority of paper examining relationship between institutional factors and earnings management, institutional factors are measured in an indirect way by using different variable such as the strength of legal environment or investor protection, control of corruption or bribery, government effectiveness, political connection, political costs.

A scarce amount of literature in accounting has documented that corruption plays an important role in accounting quality (González \& Meca, 2014; Houqe \& Monem, 2016; Kimbro, 2002; Lourenço, Rathke, Santana, \& Branco, 2018; Malagueno, Albrecht, Ainge, \& Stephens, 2010; Memis \& Cetenak, 2012; Wu, 2005) by using crosscountry data. Kimbro (2002) tests a model to exploring the effect of cultural, economic, and information variables to corruption by using cross-country data. The study indicates that the countries have higher quality of good financial reporting standards, laws enforcement, and a higher concentration of accountants are likely to be less corrupt. Similarly, Malagueno, Albrecht, Ainge, and Stephens (2010) conduct the empirical research to investigate the relationship between perceived levels of public sector corruption and accounting and auditing quality by using data from 57 countries. Consistent with the other studies, they found that the level of perceived corruption is significantly negative related to auditing quality and accounting in a country.

On other hand, with aim to better understand the role of accounting information in reducing corruption, Houqe and Monem (2016) found strong evidence that accounting environment has positive effect in the control of corruption by using data of 166 countries, however its plays only a minor role relative to the strength of political institutions. The research also suggests that countries have adopted the International Financial Reporting Standard (IFRS) without strong political institutions are not likely to achieve a reduction in corruption by way of improved financial reporting. In addition, $\mathrm{Wu}$ (2005) conduct research to focus on corruption issues in Asia, with particular emphasis on the impact of accounting practices on the bribery's degree. Author found that higher quality of accounting practices 
might reduce not only the level of bribery but also the amount of bribe payments. Recently, Lourenço, Rathke, Santana, and Branco (2018) using transparency international corruption perception index to measure corruption and its effect on earnings management by using a sample of foreign firms from 33 countries from 2011 to 2013. The paper tests the relationship between the countries' level of corruption perception and the level of earnings management. Findings indicate that in the case of emerging countries, corruption is related to higher incentives for firms to manipulate earning. Interestingly, in the case of emerging countries, corruption perceptions is related to higher manipulate earning management behavior, but opposite was true in developed countries.

In other market with weak legal protection, González and Meca (2014) conducted research in Latin America to investigate the effect of internal mechanisms of corporate governance on earnings management measured by discretionary accrual. This is the first study to analyse the relation between the effectiveness of the government and the earnings management behaviour. To measure of the governability level of country, authors used three indicators: government effectiveness, rule of law and control of corruption. These authors claim that three indicators are important factors in measuring the way in which the governability of a country affects opportunistic behaviour in firms. Authors found that when a country controls to reducing corruption, strengthen legal enforcement, or improving effectiveness of corporate governance, this lead to a reduction of firm earning management and will increase value and transparency of financial information. By comparison, Memis and Cetenak (2012) investigates the relationship between earning management and institutions measured by quality of legal system in listed private firms in different 8 emerging countries. While rule of law index and corruption index were used to measure legal system quality and effectiveness. Consistent with previous research, the judicial system helps decrease earnings management incentives.

Apart from literature, there are some researchers approaching legal system quality through protects stakeholders' right. According to some researches, a restriction degree differs in many countries derives from legal system and capital markets' development. LaPorta, Lopez-de-Silanes, Shleifer, and Vishny (1998); Leuz, Nanda, and Wysocki (2003) have the same conclusions to stated that in countries with stronger investor protection, a lower of level of earnings management is observed. Similarly, Shen, Chih, and Kang (2008) showed that lower of earnings management is found in countries with stronger investor protection and more transparent accounting disclosure.
Instead of using cross-country data, there is a growing study to examines earnings management and institutional factors by using country data with different institutional aspects such as political connections, political costs. Political connection is measured by government sales serving of US suppliers, Ngo and Susnjara (2017) test relationship between earnings management and political connection among US suppliers to government agencies. The research showed that government suppliers engage in more earnings management. Moreover, the level of sales to government agencies is positively related to the degree of earnings management. The circumstance of each country is quite different, the difference relates to the governance system.

According to Zingales (2009), political power belongs to the elected parliament in developed countries, while political power is distributed among many government departments in emerging countries. Furthermore, weak legal systems was found in emerging countries, and political power is much more easily co-opted by big corporations. Therefore, in Chen, Liang, and Wang (2011) research institutional dimension is measured by macroeconomic control, political cost to profit-taking behavior in Chinese. Authors found that whether non-stateowned real estate firms attempt to decrease earnings (by utilized more income-decreasing accruals) during periods of macroeconomic control. Two proxies were used to measure political connection, which are the executive's political connection and the state control. Executive in firms having controls are considered as having political connections that are belong to a party or parliaments or government. This study found that politically connected firms have a negative impact on degree of earnings management and also that companies tend to report lower income. The opposite was true of state-controlled firms with no significant effect on level of earnings management with income decreasing.

\section{Research Hypotheses}

Previous studies generally examine relationship between institutional factors and earnings management with diversity of the context by using different variable to measure institutions. Huther and Shah (2005), the notion of institutions linked to governance, defining governance as a "multifaceted concept encompassing all aspects of the exercise of authority through formal and informal institutions in the management of the resource endowment of a state" (p.40). This research use governance quality to measure institutions.

Additionally, the circumstances in Vietnam are quite different; especially using proxies for institutions such as 
political connection, political costs, and corruption perception index is not suitable in this market. It raises a series of problem regarding to which suitable variables could serve as alternative measures of institutions. To solve this problem, it is necessary to understand the institutions differences between Vietnam and other markets. It is believed that the crucial difference relates to the governance system. In Vietnam, power is distributed among many government departments.

The country is divided administratively into 63 provinces; provincial governments are the first level local administrative body in Vietnam. After implementation of policy reforms in Vietnam, Tran, Vu, Doan, and Tran (2016) found that law and the enforcement and compliance performance of the local authorities are large gaps between formal institutions established. According to PCI full report 2018 and Vietnam Chamber of Commerce \& Industry (VCCI) and United States Agency for International Development (USAID) (2019), the provincial governance quality across provinces has been uneven. Some provinces have improved significantly in investment and business environment and economic governance, while others lag behind.

Therefore, this research use the quality of provincial governance measured by the provincial competitiveness index (PCI). This is the measurement of the quality of public governance at province. PCI index is a performance indicator, which ranks and evaluates the quality of economic governance by provincial and city governments to promote and create a favourable business environment for the private sector. The PCI has been collected annually by the VCCI since 2007, with support from USAID. The survey covers all 63 provinces in Vietnam. Briefly, the PCI methodology was constructed in a three-step sequence: (i) collect business survey data and published data sources, (ii) calculate 10 sub-indices and standardise to a 10-point scale and (iii) calibrate the composite PCI as the weighted mean of ten sub-indices with a maximum score of 100 points (VCCI \& USAID, 2017).

The overall PCI index score comprises ten sub-indices. A province that is considered as performing well on PCI is the one that has: (1) low entry costs for business start-ups: including (i) time for firm registration and land acquisition, (ii) time for firms to gain all the necessary licenses needed to start a business as well as the degree of difficulty to obtain such licenses/permits; (2) easy access to land and security of business premises; (3) a transparent business environment and equitable business information: transparency and access to information, that is whether firms have access to proper planning and legal documents for running their business such as labour and training, whether new policies and laws are communicated to firms sufficiently and predictably implemented; (4) minimal informal charges: informal charges measuring amount of bribes paid by firms to provincial officials to measure level of corruption.

According to Rose-Ackerman (1997), corrupt officials try to delay transactions to receive more bribes from public service users; (5) limited time requirements for bureaucratic procedures and inspections; (6) minimal crowding out of private activity from policy biases toward state, foreign, or connected firms; (7) proactive and creative provincial leadership in solving problems for enterprises; (8) developed and high-quality business support services; (9) sound labour training policies; and (10) fair and effective legal procedures (legal institutions): measuring the trust from firms on provincial courts and contract enforcement. Based on the above, this research proposes the hypotheses following:

$\mathbf{H}_{\mathbf{1}}$ : There is a significant impact of provincial governance measured by overall PCI on earning management of Vietnam construction materials firms.

$\mathbf{H}_{2}$ : There is a significant impact of each sub-indices include entry cost, land access, transparency, time costs, informal charges, bias, proactivity, business support services, labor training policies, legal institutions on earnings management of Vietnam construction materials companies.

\section{Research Methodology}

\subsection{Data Collection}

In this study, ten sub-indices for each province were taken from Provincial Competitiveness Index (PCI) report annual which is result of on-going collaborative effort between the Vietnam Chamber of Commerce and Industry (VCCI) and the U.S. Agency for International Development (USAID)-funded Vietnam Competitiveness Initiative (VNCI), managed by DAI, with a substantial contribution by VNCI partner The Asia Foundation (TAF) for a purpose of evaluating institutional quality of provincial or local governments. In addition, financial data has been collected from financial statements of 52 construction materials companies listed on Vietnamese stock market includes Hanoi stock exchange (HNX) and Ho Chi Minh stock exchange (HOSE), which operate in 25 provinces for the period of 2015-2017. 


\subsection{Measure of Earnings Management (Dependent Variable)}

Consistent with previous research, this research used discretionary accruals to measure earnings management, which were found in many earnings management studies (Ball \& Shivakumar, 2008; Jones, 1991) used average total assets as a deflator to address concerns related to strong growth in assets (to reduce the large discretionary accrual

estimation) and to correct for the small-denominator problem. Basically, we used model developed by Kothari, Leone, and Wasley (2005) to obtain the discretionary (abnormal) accruals (independent variable) for measuring earnings management which are obtained by following equations:

$\mathrm{TAt} / \mathrm{A}(\mathrm{t}-1+\mathrm{t}) / 2=(\mathrm{NIBEi}, \mathrm{t}-\mathrm{CFO}, \mathrm{t}) / \mathrm{A}(\mathrm{t}-1+\mathrm{t}) / 2$

TAt $=$ Total Accruals

DAt $=$ Discretionary Accruals

NDAt $=$ Nondiscretionary Accruals

NIBEi,t = company i's net income before extraordinary items in year $\mathrm{t}$

CFOi,t = company i's net cash flow from operations in year $\mathrm{t}$

$\mathrm{Ai},(\mathrm{t}-1+\mathrm{t}) / 2$ : average of beginning and end of year total asset

$\mathrm{REV}_{\mathrm{it}}$ : is revenues in year $\mathrm{t}$ less revenues in year $\mathrm{t}-1$

$\mathrm{REC}_{\mathrm{it}}$ : is net receivables in the year $\mathrm{t}$ less net receivable in year $\mathrm{t}-1$

$\mathrm{PPE}_{\mathrm{it}}$ : gross property plant and equipment ath the end of year $\mathrm{t}$

$\alpha_{1}, \alpha_{1}, \alpha_{1}$ : Industry-specific parameters

\subsection{Measure of Provincial Governance}

As analysis above, this research emphasis on investigating an appropriate proxy for provincial governance by using overall PCI and ten sub-indices of PCI which are a leading measurement regarding institutions in Vietnam.

\subsection{Regression Models}

Four models have been used in our research to test hypothesis. Absolutely, dependent variable is Discretionary Accruals (DA) is at four models as an indicator of earnings management. This study use both aggregated index (PCI) and ten sub-indicators to measure institutional factors at the provincial level. The main independent variable PCI overall index, and 10 sub-indices include: entry cost, land access, transparency, time costs, informal charges, bias, proactivity, business support services, labor training policies, legal institutions, which were taken from Provincial Competitiveness Index (PCI) report. In consistent with the accounting literature, this paper has used control variables: first auditor dummy is a proxy for audit quality (big4), in addition, another dummy variable to indicate firms reporting negative or positive earnings (loss or gain). So as to explore whether the impacts of governance quality on earnings management's degree is lower in companies with losses, when compared to companies with gains, interactions of each company with this dummy is added in our model that indicated the type of company (losses versus gains). These interactions are necessary to evaluate any differences in the effect of this quality of provincial governance variables between losses and gains firms.

In order to control diversity of earnings management incentives based on characteristics of firms related to accruals. A number of group of control variables is added in this study such as: company size (SIZE) is computed by natural logarithm of a company's total financial year assets, return on total assets (ROA) as a measure for corporate operating conditions/current economic condition of firms which may have an effect on company's choice of accounting policy. As the result, the following models are:

$$
\begin{aligned}
& \mathrm{DA}_{\mathrm{i}, \mathrm{t}}=\beta_{0}+\beta_{1} \mathrm{PCI}_{\mathrm{i}, \mathrm{t}}+\beta_{2} \mathrm{BIG}_{\mathrm{i}, \mathrm{t}}+\beta_{3} \mathrm{ROA}_{\mathrm{i}, \mathrm{t}}+\beta_{4} \mathrm{SIZE}_{\mathrm{i}, \mathrm{t}} \\
+ & \beta_{5} \mathrm{LOSS}_{\mathrm{i}, \mathrm{t}}+\varepsilon \\
& \mathrm{DA}_{\mathrm{i}, \mathrm{t}}=\beta_{0}+\beta_{1} \mathrm{PCI}_{\mathrm{i}, \mathrm{t}}+\beta_{2} \mathrm{BIG}_{\mathrm{i}, \mathrm{t}}+\beta_{3} \mathrm{ROA}_{\mathrm{i}, \mathrm{t}}+\beta_{4} \mathrm{SIZE}_{\mathrm{i}, \mathrm{t}} \\
+ & \beta_{5} \mathrm{LOSS}_{\mathrm{i}, \mathrm{t}}+\beta_{6} \mathrm{LOSS}_{\mathrm{i}, \mathrm{t}} * \mathrm{PCI}_{\mathrm{i}, \mathrm{t}}+\varepsilon
\end{aligned}
$$




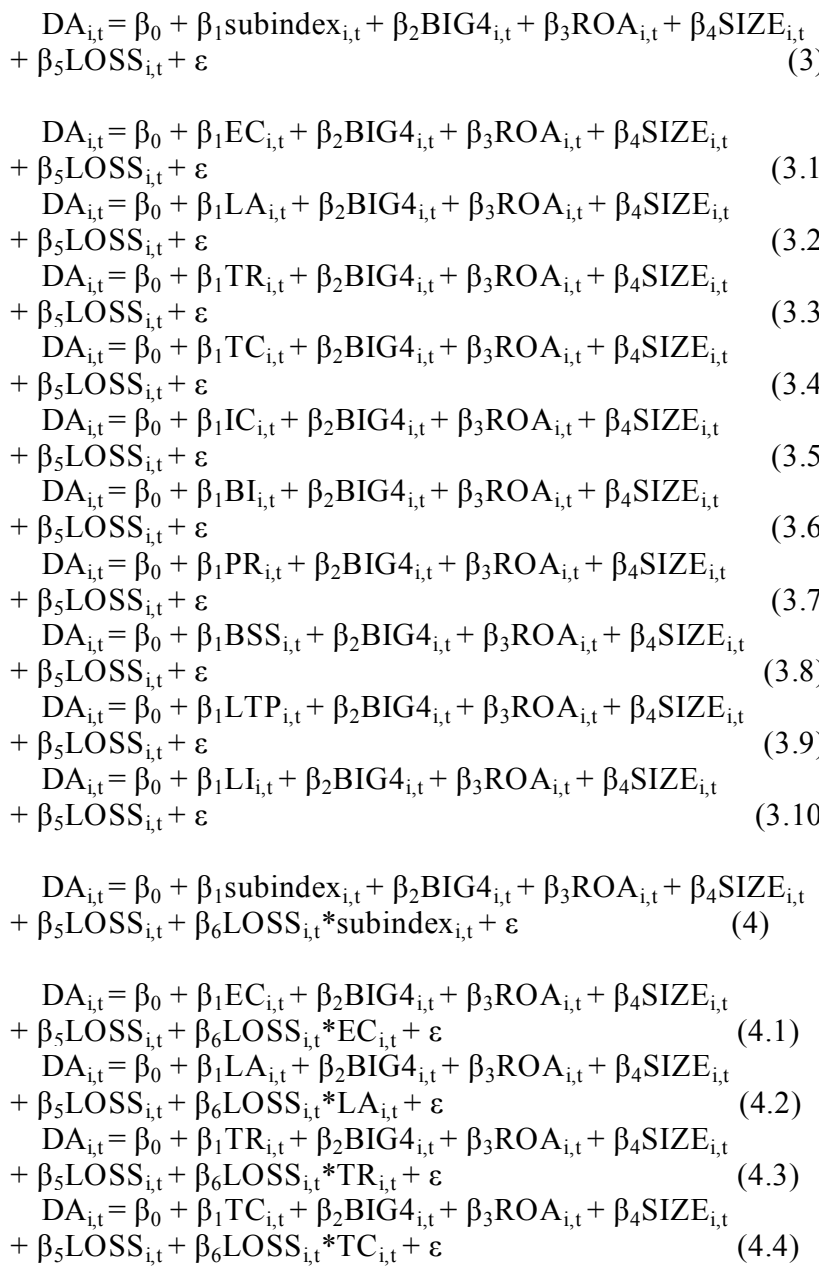

$$
\begin{aligned}
& \mathrm{DA}_{\mathrm{i}, \mathrm{t}}=\beta_{0}+\beta_{1} \mathrm{IC}_{\mathrm{i}, \mathrm{t}}+\beta_{2} \mathrm{BIG}_{\mathrm{i}, \mathrm{t}}+\beta_{3} \mathrm{ROA}_{\mathrm{i}, \mathrm{t}}+\beta_{4} \mathrm{SIZE}_{\mathrm{i}, \mathrm{t}} \\
& +\beta_{5} \mathrm{LOSS}_{\mathrm{i}, \mathrm{t}}+\beta_{6} \mathrm{LOSS}_{\mathrm{i}, \mathrm{t}}{ }^{*} \mathrm{IC}_{\mathrm{i}, \mathrm{t}}+\varepsilon \\
& \mathrm{DA}_{\mathrm{i}, \mathrm{t}}=\beta_{0}+\beta_{1} \mathrm{BI}_{\mathrm{i}, \mathrm{t}}+\beta_{2} \mathrm{BIG}_{\mathrm{i}, \mathrm{t}}+\beta_{3} \mathrm{ROA}_{\mathrm{i}, \mathrm{t}}+\beta_{4} \mathrm{SIZE}_{\mathrm{i}, \mathrm{t}} \\
& +\beta_{5} \operatorname{LOSS}_{\mathrm{i}, \mathrm{t}}+\beta_{6} \mathrm{LOSS}_{\mathrm{i}, \mathrm{t}} * \mathrm{BI}_{\mathrm{i}, \mathrm{t}}+\varepsilon \\
& \mathrm{DA}_{\mathrm{i}, \mathrm{t}}=\beta_{0}+\beta_{1} \mathrm{PR}_{\mathrm{i}, \mathrm{t}}+\beta_{2} \mathrm{BIG}_{\mathrm{i}, \mathrm{t}}+\beta_{3} \mathrm{ROA}_{\mathrm{i}, \mathrm{t}}+\beta_{4} \mathrm{SIZE}_{\mathrm{i}, \mathrm{t}} \\
& +\beta_{5} \operatorname{LOSS}_{\mathrm{i}, \mathrm{t}}+\beta_{6} \mathrm{LOSS}_{\mathrm{i}, \mathrm{t}} * \mathrm{PR}_{\mathrm{i}, \mathrm{t}}+\varepsilon \\
& \mathrm{DA}_{\mathrm{i}, \mathrm{t}}=\beta_{0}+\beta_{1} \mathrm{BSS}_{\mathrm{i}, \mathrm{t}}+\beta_{2} \mathrm{BIG}_{\mathrm{i}, \mathrm{t}}+\beta_{3} \mathrm{ROA}_{\mathrm{i}, \mathrm{t}}+\beta_{4} \mathrm{SIZE}_{\mathrm{i}, \mathrm{t}} \\
& +\beta_{5} \operatorname{LOSS}_{\mathrm{i}, \mathrm{t}}+\beta_{6} \operatorname{LOSS}_{\mathrm{i}, \mathrm{t}} * \mathrm{BSS}_{\mathrm{i}, \mathrm{t}}+\varepsilon \\
& \mathrm{DA}_{\mathrm{i}, \mathrm{t}}=\beta_{0}+\beta_{1} \mathrm{LTP}_{\mathrm{i}, \mathrm{t}}+\beta_{2} \mathrm{BIG}_{\mathrm{i}, \mathrm{t}}+\beta_{3} \mathrm{ROA}_{\mathrm{i}, \mathrm{t}}+\beta_{4} \mathrm{SIZE}_{\mathrm{i}, \mathrm{t}} \\
& +\beta_{5} \operatorname{LOSS}_{\mathrm{i}, \mathrm{t}}+\beta_{6} \operatorname{LOSS}_{\mathrm{i}, \mathrm{t}} * \mathrm{LTP}_{\mathrm{i}, \mathrm{t}}+\varepsilon \\
& \mathrm{DA}_{\mathrm{i}, \mathrm{t}}=\beta_{0}+\beta_{1} \mathrm{LI}_{\mathrm{i}, \mathrm{t}}+\beta_{2} \mathrm{BIG}_{\mathrm{i}, \mathrm{t}}+\beta_{3} \mathrm{ROA}_{\mathrm{i}, \mathrm{t}}+\beta_{4} \mathrm{SIZE}_{\mathrm{i}, \mathrm{t}} \\
& +\beta_{5} \operatorname{LOSS}_{\mathrm{i}, \mathrm{t}}+\beta_{6} \operatorname{LOSS}_{\mathrm{i}, \mathrm{t}} * \mathrm{LI}_{\mathrm{i}, \mathrm{t}}+\varepsilon
\end{aligned}
$$

where: $\mathrm{DA}_{\mathrm{it}}=$ Absolute value of discretionary portion of total accruals for firm $i$ in year $t$, calculated by model above. BIG4 $_{\text {it }}=$ Audit Quality Dummy Variable (if company works with Big 4 auditor $=1$, otherwise $=0$ ) for firm $\mathrm{i}$ in year $\mathrm{t}$

$\mathrm{ROA}_{\mathrm{it}}=$ Return on total assets for firm $\mathrm{i}$ in year $\mathrm{t}$

$\mathrm{SIZE}_{\text {it }}=$ Natural logarithm of total assets for firm i in year $\mathrm{t}$ LOSS $_{\mathrm{it}}$ : dummy variable (if company loss $=1$, otherwise $=0$ ) for firm $i$ in year $t$.

$\mathrm{PCI}_{\mathrm{it}}$ : overall PCI index for firm $\mathrm{i}$ for each province in year $\mathrm{t}$

Subindex $x_{\text {it: }} 10$ sub-indices to be tested one by one to test it's effect on earning management: entry cost (EC), land access (LA), transparency (TR), time costs (TC), informal charges (IC), bias (BI), proactivity (PR), business support services (BSS), labor training policies (LTP), legal institutions (LI).

After collecting the raw data and calculating the proxies, the data was then regression by steps for further analysis. Figure 1 presents the steps to choose the preferred model for panel data for the both model 1 and 2 .

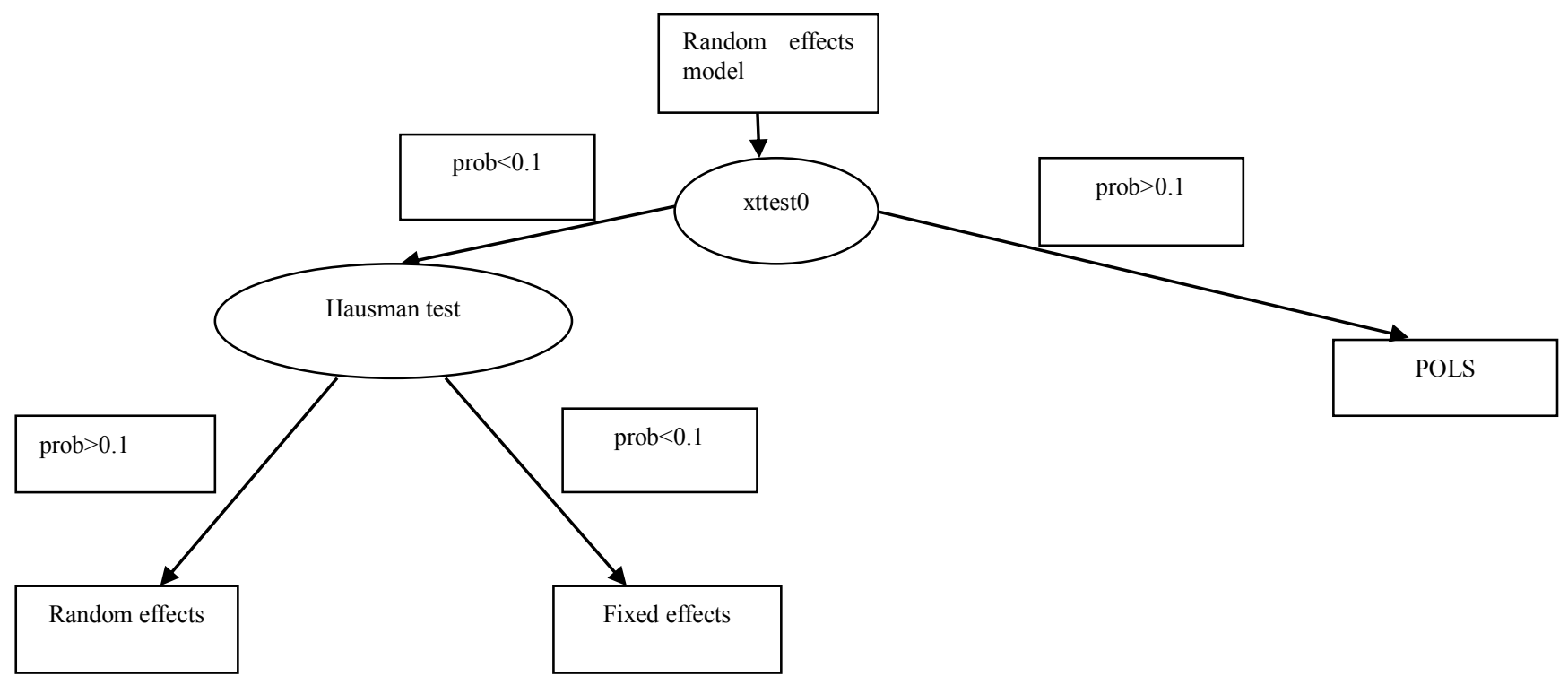

Figure 1: Steps to choosing model for panel data 


\section{Results and Discussion}

\subsection{Descriptive Statistics}

Table 1 and chart 1 show the description of statistics of the main variables used in this research for 156 observations included in the sample for 25 provinces. While size of sample firms is relatively similar, level of accruals (earnings management) of firms is large different (with min -0.5104241 to $\max 0.3222477$ ). Figure 2 describes average of DA and PCI for 25 provinces for the period of 2015 to 2017. Da Nang have the highest index of PCI, the opposite was true of Yen Bai and An Giang province. Respectively higher accruals estimated for Hue, while Lang Son has lower amount through period of 2015 to 2017. In summary, provinces shows opposite trend between PCI and DA for example in the case of Lang Son (LS) province in which average of PCI hit lowest point while level of DA is relatively high.

Table 1: Descriptive statistics for regression variables

\begin{tabular}{|c|c|c|c|c|}
\hline Variable & Mean & Std. Dev. & Min & Max \\
\hline DA & -0.0199 & 0.1094 & -0.5104 & 0.3222 \\
\hline ROA & 0.0424 & 0.1001 & -0.3455 & 0.3739 \\
\hline SIZE & 26.8027 & 1.382 & 24.0777 & 30.4057 \\
\hline PCI & 61.6730 & 3.4387 & 54.6139 & 70.694 \\
\hline
\end{tabular}

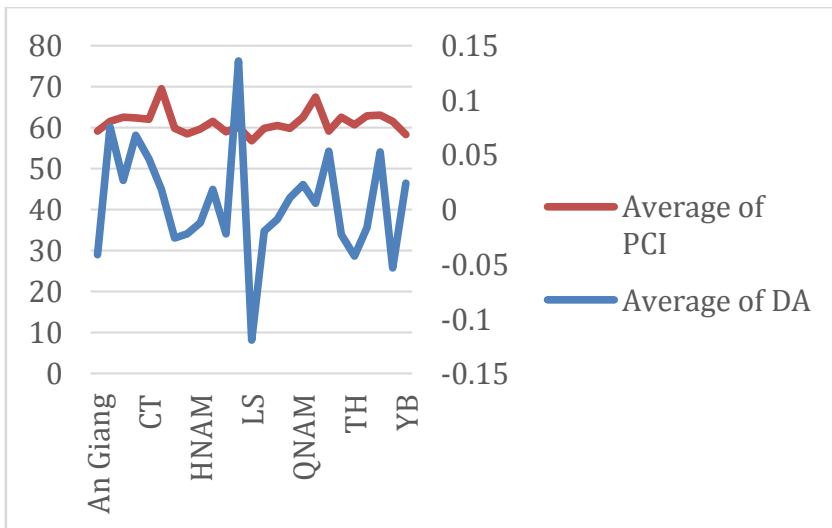

Figure 2: Average of DA and Average of PCI for 25 provinces (2015-2017)

\subsection{Regression Analysis}

With the test of xttest 0 has result of prob $>0.1$ for models $1,2,3$, and 4, thus POLS model is chosen model for all models in this research. Subsequently, one by one of imtest, ovtest, hettest were applied to test heteroskedasticity and checks for violation in the normality of residuals distribution, omitted variables. As the result, the model is perfectly suitable to implement POLS regression.
Table 2: Regressions results for model 1

\begin{tabular}{|c|c|c|c|c|c|}
\hline & ROA & SIZE & BIG4 & PCI & LOSS \\
\hline DA & $0.2432^{* *}$ & 0.0055 & $-0.0469^{* *}$ & 0.0027 & -0.0353 \\
\hline \multicolumn{6}{|c|}{ Cons $=-0.3336$} \\
\hline \multicolumn{6}{|c|}{ Prob $=0.0004$} \\
\hline \multicolumn{7}{|c|}{ R-squared $=0.1378$} \\
\hline$* * * *$ and * indicate significant at the levels respectively 1\%, 5\%
\end{tabular}
and $10 \%$

Only two variables, ROA and BIG4 have an effect on discretionary accruals. Returns on assets (ROA) are significantly and positively at $5 \%$ associated with earnings management. While big4 have negative significant coefficient at $5 \%$, which indicates audit quality can reduce earnings management incentives. However, there are not significant relationships between size, PCI and earnings management (measured by DA).

Table 3: Regressions results for model 2

\begin{tabular}{|l|l|l|l|l|l|l|}
\hline & ROA & SIZE & BIG4 & PCI & LOSS & $\begin{array}{l}\text { LOSS* } \\
\text { PCI }\end{array}$ \\
\hline DA & $0.2553^{* *}$ & 0.0073 & $-0.0493^{* * *}$ & $0.0044^{*}$ & $0.5575^{*}$ & $-0.0097^{*}$ \\
\hline Cons $=-0.4890$ \\
\hline
\end{tabular} Prob $=0.0000$
R-squared $=0.1508$
*** ** and * indicate significant at the levels respectively 1\%, 5\%
and $10 \%$

Table 3 illustrates the results of the regression models performed relationship between earnings management's degree of materials firms and the level the quality of provincial governance in their respective provinces. The table presents the analysis of capturing the differences between loss and gain firms. The regression is estimated with robust standard errors. Regarding the firm characteristics variables, the coefficient of ROA is positive and statistically significant at 5\%. All audit quality (big4 clients) have lower discretionary accruals, there are statistically significant difference at $1 \%$, while the coefficient of the variable firm size are not significant statistically. Table 3 shows the analysis of capturing any differences between firms with loss and gain. The table shows that only in the group of firms with loss, the coefficient of the dummy variable Loss is positive and statistically significant at $10 \%$. Consistent with above finding, the results presented in table 3 found that the estimate of PCI variable is positive while the coefficient of the interaction term of dummy variable Loss with PCI is statistically significant and negatively. It seems that the PCI variable can explains the earnings management's degree but only in the group of companies with loss. Which means that, in the companies with loss, the relationship between the level of PCI and the level of earnings management is negative $(0.0044-0.0097=-0,0053)$. 
Table 4 illustrates effect of each sub-index of PCI on earnings management. Regarding the firm characteristics variables, the coefficients of ROA are positive and statistically significant at 10\% (for Entry Cost, Time Cost, Proactivity, Legal Institution) at 5\% for last sub-indices, while the coefficient of the variable big4 is negative also statistically significant at $1 \%$ and $5 \%$. However, the coefficients of ten sub-indices is not statistically significant, which mean that the relationship between level of each sub-

with loss showing that coefficient of the three independent variables are negative and statistically significant at $5 \%$ Transparency (TR), $1 \%$ for Informal Charges (IC), 10\% for Proactivity (PR) (Sub-index (i)*loss). It seems that, in company with loss, a lower corruption's degree-lower amount of firms paid in informal charges, an obstacle those extra fees pose for their business operations indices and level of earnings management can not be found in firms.

Table 5 shows the association between each sub-indices and earnings management for whole sample but capturing any differences between losses and gain firms. ROA and big 4 are the variables firm-level keep the same meaning as result of model 1, 2, 3. Only in Transparency (TR), Informal Charges (IC), Proactivity (PR) are found in firms

(which means a higher value of the informal charge index) is related with a lower earnings management's degree. Similarly, a higher of level transparency (which means a higher value of the transparency index) and a higher of level proactivity (which means a higher value of proactivity of provincial leadership index) is related to a lower earnings management behavior.

Table 4: Regressions results for models from 3.1 to 3.10

\begin{tabular}{|c|c|l|l|l|l|l|l|l|}
\hline Model 3 & Sub-indices & ROA & SIZE & BIG4 & LOSS & Cons & \multicolumn{1}{c|}{ Prob } & \multicolumn{1}{c|}{ R-squared } \\
\hline (3.1) DA & Entry Costs (EC): -0.015 & $0.234^{*}$ & 0.005 & $-0.044^{* *}$ & -0.044 & -0.014 & 0.0001 & 0.1379 \\
\hline (3.2) DA & Land Access (LA): 0.003 & $0.245^{* *}$ & 0.006 & $-0.047^{* *}$ & -0.038 & -0.1934 & 0.0002 & 0.1311 \\
\hline (3.3) DA & Transparency (TR) :-0.038 & $0.244^{* *}$ & 0.006 & $-0.047^{* *}$ & -0.038 & -0.1940 & 0.0001 & 0.1309 \\
\hline (3.4) DA & Time Costs (TC): 0.012 & $0.233^{*}$ & 0.007 & $-0.047^{* *}$ & -0.035 & -0.273 & 0.0001 & 0.1348 \\
\hline (3.5) DA & Informal Charges (IC): 0.005 & $0.245^{* *}$ & 0.006 & $-0.047^{* *}$ & -0.0368 & -0.209 & 0.0002 & 0.1317 \\
\hline (3.6) DA & Bias (BI): 0.003 & $0.245^{* *}$ & 0.006 & $-0.046^{* *}$ & -0.039 & -0.189 & 0.0002 & 0.1310 \\
\hline (3.7) DA & Proactivity (PR): 0.008 & $0.241^{*}$ & 0.006 & $-0.048^{* *}$ & -0.036 & -0.226 & 0.0001 & 0.1343 \\
\hline (3.8) DA & Business Support Services (BSS): 0.0150 & $0.255^{* *}$ & 0.004 & $-0.047^{* * *}$ & -0.040 & -0.221 & 0.0001 & 0.1414 \\
\hline (3.9) DA & Labor Training Policies (LTP): 0.005 & $0.245^{* *}$ & 0.005 & $-0.046^{* *}$ & -0.038 & -0.183 & 0.0002 & 0.1317 \\
\hline (3.10) DA & Legal Institutions (LI): 0.013 & $0.239^{*}$ & 0.007 & $-0.049^{* * *}$ & -0.036 & -0.280 & 0.0001 & 0.1365 \\
\hline
\end{tabular}

$* * *, * *$ and $*$ indicate significant at the levels respectively $1 \%, \quad 5 \%$ and $10 \%$

Table 5: Regressions results for models from 4.1 to 4.10

\begin{tabular}{|c|c|c|c|c|c|c|c|c|c|}
\hline Model 4 & Sub-indices & ROA & SIZE & BIG4 & LOSS & Loss*Sub & Cons & Prob & R-squared \\
\hline (4.1) DA & $\begin{array}{c}\text { Entry Costs (EC): - } \\
0.006\end{array}$ & $0.254 * *$ & 0.0072 & $-0.048 * * *$ & 0.355 & -0.0493 & -0.1592 & 0.0000 & 0.1477 \\
\hline (4.2) DA & $\begin{array}{c}\text { Land Access (LA): } \\
0.0091\end{array}$ & $0.234^{*}$ & 0.0068 & $-0.045 * *$ & 0.079 & -0.0208 & -0.252 & 0.0004 & 0.1350 \\
\hline (4.3) DA & $\begin{array}{c}\text { Transparency (TR): } \\
0.0192\end{array}$ & $0.232 *$ & 0.0065 & $-0.044 * *$ & $0.552^{*}$ & $-0.0951^{* *}$ & -0.314 & 0.0002 & 0.1440 \\
\hline (4.4) DA & $\begin{array}{c}\text { Time Costs (TC): } \\
0.0221 \\
\end{array}$ & $0.246^{* *}$ & 0.008 & $-0.044 * *$ & 0.309 & -0.054 & -0.382 & 0.000 & 0.1471 \\
\hline (4.5) DA & $\begin{array}{c}\text { Informal Charges (IC): } \\
0.0175\end{array}$ & $0.266^{* *}$ & 0.0104 & $-0.055^{* * *}$ & $0.439^{* * *}$ & $-0.096 * * *$ & -0.387 & 0.000 & 0.1607 \\
\hline (4.6) DA & $\begin{array}{c}\text { Bias (BI): } \\
0.0120\end{array}$ & $0.223^{*}$ & 0.0078 & $-0.048 * *$ & 0.1534 & -0.041 & -0.280 & 0.000 & 0.1404 \\
\hline (4.7) DA & $\begin{array}{c}\text { Proactivity (PR): } \\
0.0159\end{array}$ & $0.244 * *$ & 0.0092 & $-0.051 * * *$ & 0.1711 & $-0.0435^{*}$ & -0.342 & 0.000 & 0.1485 \\
\hline (4.8) DA & $\begin{array}{c}\text { Business Support } \\
\text { Services (BSS): } 0.0139\end{array}$ & $0.256^{* *}$ & 0.0042 & $-0.046^{* *}$ & -0.0933 & 0.008 & -0.215 & 0.000 & 0.1418 \\
\hline (4.9) DA & $\begin{array}{l}\text { Labor Traning Policies } \\
\text { (LTP): } 0.0085\end{array}$ & $0.260^{* *}$ & 0.0050 & $-0.047 * * *$ & 0.0787 & -0.017 & -0.208 & 0.0004 & 0.1341 \\
\hline (4.10)DA & $\begin{array}{c}\text { Legal Institutions (LI): } \\
0.009\end{array}$ & $0.240^{*}$ & 0.0066 & $-0.0487 * *$ & -0.133 & 0.018 & -0.243 & 0.0001 & 0.1383 \\
\hline
\end{tabular}

$* * *, * *$ and $*$ indicate significant at the levels respectively $1 \%, 5 \%$ and $10 \%$ 


\section{Implications and Conclusion}

\subsection{Implications}

In light of the above, these findings have several implications for investors, auditors, local authorities. First, for investors, it raises concerning the important of quality of provincial governance in which transparency, informal charges, proactiveness and creativeness of provincial leadership have negative impacts on earning management. Hence, they should be wise when observing a high magnitude of earnings in buying stocks of firms operating in provinces with weak business environment. Second, for auditors, the auditor should be more careful when auditing financial statement of firm located in regions having poor provincial governance quality. Finally, according to empirical research, provincial governance quality have an important influence on the earning management. The improvement of the business environment, in which encourages firms to invest and improve real business performance rather than accruals. Based on the findings of this study, the paper make some recommendations for local authorities to improve the quality of institutions by improve some indicators. Specifically:

As for transparency and access to information, in order to enhance a transparent mechanism for enterprises access to information and constrain the negative things such as "VCCI \& USAID argue that if you want to have information, you have to pay" (2016, p.90), local authorities are necessary required to review, supplement, amend relevant documents, regulate the confidentiality and restriction of confidentiality of non-confidential information with the participation of enterprises based on legal framework of central government. In addition, local authorities should be committed to timely to make sure that such information is available and communicated to enterprises as accurately and fairly as possible in an appropriate manner.

As for informal charges, to reduce unofficial costs, the followings actions need to be taken: (1) The duration of administrative procedures should be as short as possible and reinforce administrative disciplines, (2) improve the quality of the one-stop-shop agencies by increasing transparency and clarity of service regulations, procedures, and fees. As for proactiveness and creativeness of provincial leadership, in order to strengthen the positive influence of creative ideas of local authorities to enterprises, local authorities should pay attention to hearing the voice of representatives of business associations and enterprises. Therefore, It is important to set up a hotline and email addresses of person at all levels on the provincial who are in charge of the problems. Understanding enterprises' requirements in order to quickly resolve theirs difficulties and obstacles, annual forums or meeting with enterprises and investors should be organized.

\subsection{Conclusion}

This research explores the impact of provincial governance quality measured by the Provincial Competitiveness Index (the measurement of the quality of public governance at province) on earnings management in the context of Vietnam by using 52 firms' observations of listed construction materials companies across different 25 provinces. Regarding the firm-level variables, ROA and big4 have impacts on earnings management. In consistent with the literature, this research has suggested differentiation between Big4 and non-Big4 audit firms, which represent audit quality effects earnings management incentives. In addition, the empirical findings suggest that higher quality of economic governance by provincial authorities is associated to lower incentives for companies to manipulate earnings for companies with loss, while such results are not identified in companies with gain.

The results also indicate that informal charges index is found to be the most important determining variable it has significant and negative relation with earnings management, followed by transparency index and proactivity index. The findings consist with results of previous researches pertaining to the effect of corruption or institution on earnings management such as (Houeqe \& Monem, 2016; Riahi-Belkaoui, 2004). The study suggests the existence of threshold level of quality of provincial governance, below which the effects on earnings management are no longer significant. In other words, another contributes for literature review is that the research uses indicator measure of real phenomenon of institutions instead of using perceptions index like some previous studies.

\section{References}

Ball, R., Kothari, S. P., \& Robin, A. (2000). The effect of international institutional factors on properties of accounting. Journal of Accounting and Economics, 29(1), 1-51.

Ball, R., \& Shivakumar, L. (2008). Earnings quality at initial public offerings. Journal of Accounting and Economics, 45(2-3), 324-349.

Chen, D., Li, J., Liang, S., \& Wang, G. (2011). Macroeconomic control, political costs and earnings management: Evidence from Chinese listed real estate companies. China Journal of Accounting Research, 4(3), 91-106.

González, J. S., \& Meca, E. G. (2014). Does corporate governance influence earnings management in 
Latin American markets? Journal of Business Ethics, 121(3), 419-440

Healy, P. M., \& Wahlen, J. M. (1999). A review of the earnings management literature and its implications for Standard Setting. Accounting Horizons, 13(1), 365-383.

Hoskisson, R. E., Eden, L., Lau, C. M., \& Wright, M. (2000). Strategy in emerging economies. Academy of Management Journal, 43(3), 249-267.

Houqe, N., \& Monem, R. (2016). Corruption, political institutions, and accounting environment: A cross-country study. International Journal of Accounting Symposium, 5(1), 363-378.

Huther, J., \& Shah, A. (2005). A simple measure of good Governance. Retrieved November 18, 2019, from http://siteresources.worldbank.org/INTWBIGOVA NTCOR/Resources/SimpleMeasure ofGoodGovernance.pdf

Jones, J. J. (1991). Earnings management during import relief investigations. Journal of Accounting Research, 29(2), 193-228.

Kimbro, M. B. (2002). A cross-country empirical investigation of corruption and its relationship to economic, cultural, and monitoring institutions: an examination of the role of accounting and financial statements quality. Journal of Accounting, Auditing and Finance, 17(4), 325-349.

Kothari, S. P., Leone, A., \& Wasley, C. E. (2005). Performance matched discretionary accrual measures. Journal of Accounting and Economics, 39(1), 163-197.

LaPorta, R., Lopez-de-Silanes, F., Shleifer, A., \& Vishny, R. (1998). Law and finance.

Journal of Political Economy, 106(6), 1113-1155.

Leuz, C., Nanda, D., \& Wysocki, P. D. (2003). Earnings management and investor protection: An international comparison. Journal of Financial Economics, 69(3), 505-527

Lourenço, I. C., Rathke, A., Santana, V., \& Branco, M. C. (2018). Corruption and earnings management in developed and emerging countries. Corporate Governance: The International Journal of Business in Society, 18(1), 35-51.

Malagueno, R., Albrecht, C., Ainge, C., \& Stephens, N. (2010). Accounting and corruption: A crosscountry analysis. Journal of Money Laundering Control, 13(4), 372-393.

Memis, M., \& Cetenak, E. (2012). Earnings management, audit quality and legal environment: An international comparison. International Journal of Economics and Financial Issues, 2(4), 460-469.

Ngo, T., \& Susnjara, J. (2017). The effect of political connections on earnings management: The evidence from government suppliers. Retrieved November 18, 2019, from https://efmaefm.org/0EFMAMEETINGS/EFMA\%20A NNUAL\%20MEETINGS/201 7Athens/papers/EFMA2017_0369_fullpaper.pdf

Riahi-Belkaoui, A. (2004). Effects of corruption on earnings opacity internationally. Advances in International Accounting, 17(4), 73-84.

Rose-Ackerman, S. (1997). Role of the World Bank in controlling corruption. Law \& Policy International Business, 29(93), 119-141.

Shen, C. H., Chih, H. L., \& Kang, F. C. (2008). Corporate social responsibility, investor protection, and earnings management: Some international evidence. Journal of Business Ethics, 79(1), 179-198.

Tran, Q. T., Vu, V. H., Doan, T. T., \& Tran, D. H. (2016). Corruption, provincial institutions and manufacturing firm productivity: New evidence from a transitional economy. Estudios de Economia, 43(2), 199-215. doi: $10.4067 / \mathrm{S} 0718-52862016000200002$

Viet Nam Chamber of Commerce and Industry (VCCI) and the US Agency for International Development (USAID). (2019, March 28). The Provincial Competitiveness Index (PCI) 2018. Retrieved August 29, 2019, from http://eng.pcivietnam.org/catalog-of-publications/pcifull-reports

Viet Nam Chamber of Commerce and Industry (VCCI) and the US Agency for International Development (USAID). (2017, March 14). The Provincial Competitiveness Index (PCI) 2016. Retrieved August 29, 2019, from http://eng.pcivietnam.org/publications/full-report-20162/

Viet Nam Chamber of Commerce and Industry (VCCI) and the US Agency for International Development (USAID). (2016, March 31). The Provincial Competitiveness Index (PCI) 2015. Retrieved August 29, 2019, from http://pcivietnam.org/an-pham/bao-cao-pci-2015/

$\mathrm{Wu}$, X. (2005). Firm accounting practices, accounting reforms and corruption in Asia. Policy and Society, 24(3), 53-78.

Zingales, L. (2009). The Future of securities regulation. Journal of Accounting Research. 47(2), 391-425. 